\title{
A Probe into the Teaching Path of Music Appreciation Course in Colleges and Universities from the Perspective of Aesthetic Education
}

\author{
Zhao Yiran \\ College of Music and Dance, Sichuan Technology and Business University, Chengdu, Sichuan, \\ China
}

Keywords: aesthetic education; music appreciation class; colleges and universities; teaching

\begin{abstract}
Under the current situation, the work of aesthetic education in colleges and universities has received more and more attention from the country. The research and practice of aesthetic education in colleges and universities has become the focus of social attention. Classroom teaching in colleges and universities is an important position for the practice of aesthetic education. The author takes the music appreciation class in ordinary colleges and universities as the entry point, explores the teaching path from the perspective of aesthetic education, and puts forward the following point of view: aesthetic education is to cultivate students' aesthetic perception and at the same time stimulate students' understanding of humanities. The comprehensive improvement of literacy and artistic literacy cultivates students' noble character and improves their physical and mental health; in the teaching of music appreciation classes, teachers and students are used to dialogue and share discussions on an equal footing, to stimulate students' perception and thinking of beauty, so as to cultivate students' thinking ability; In the teaching of music appreciation class, teachers guide and students experience ways to cultivate students' ability to discover beauty, recognize beauty, feel beauty, and express beauty.
\end{abstract}

\section{Introduction}

In recent years, China's specific requirements for aesthetic education in higher education have been significantly enhanced. As early as 2015, the State Council issued "Opinions on Comprehensively Strengthening and Improving School Aesthetic Education", which pointed out that "Aesthetic education courses in ordinary colleges and universities should rely on the advantages of relevant disciplines of the school. With the advantages of local educational resources, expand the content and forms of education and teaching, guide students to improve their personality cultivation, strengthen students' awareness of cultural subjectivity and cultural innovation, and enhance students' sense of responsibility and mission to inherit and promote the excellent Chinese culture and art." Later, in 2019 In the "Opinions of the Ministry of Education on Effectively Strengthening the Aesthetic Education Work of Colleges and Universities in the New Era" promulgated by the Ministry of Education, the overall goal of the aesthetic education work in 
colleges and universities is that "by 2022, colleges and universities have made breakthroughs in aesthetic education, and the reform of aesthetic education and teaching has achieved remarkable results. The construction and venue facilities have been significantly strengthened, the promotion mechanism and evaluation system have been improved, and the aesthetic and humanistic qualities of college students have been significantly improved. By 2035, a diversified, high-quality, modern socialist college aesthetic education system with Chinese characteristics will be formed."

A series of policies on aesthetic education that my country has successively promulgated have gradually pushed the aesthetic education work of colleges and universities to a distinct position, and the development of aesthetic education in colleges and universities has become unstoppable. In terms of the current educational situation in colleges and universities, the implementation of aesthetic education needs to combine the original disciplines and courses of colleges and universities, and continuously carry out teaching reforms that integrate aesthetic education in practice, and propose new explorations and new paths in the field of aesthetic education. In this article, the author takes the music appreciation class of ordinary colleges and universities as the entry point, and combines the specific requirements of the development of aesthetic education in colleges and universities, and explores the teaching path of ordinary high school music appreciation from the perspective of aesthetic education. This article will be divided into three parts: first, discuss the role of aesthetic education and the significance of aesthetic education in the development of music education in colleges and universities; second, analyze the current situation of college music appreciation courses, and point out the problems in the teaching of music appreciation courses in ordinary colleges and universities; , Put forward the teaching path in the music appreciation class of ordinary colleges and universities from the perspective of aesthetic education.

\section{Analysis of the role and significance of aesthetic education in education}

Education is a human practice activity that cultivates, promotes, and promotes human development. The development of education is inseparable from the vigorous development of the country's economy, politics, technology, and culture. When people's living standards improve and their happiness index rises, people gradually begin to pay attention to people's self-feelings, and gradually begin to understand life and culture. A sense of experience and needs are gradually emerging from various aspects such as, society, etc. This sense of experience and needs emphasizes people's perception abilities at this time, and the continuous attention and development of aesthetic education in Chinese education is the development and development of people. A new direction proposed by education in the context of a new social development. Aesthetic education is called "aesthetic education" or "aesthetic education". It is a part of quality education. It is a practical activity of cultivating students' "aesthetic sense" from an aesthetic point of view. It is an education of perception and cognition. Beautiful things can be perceived, and the perception of beauty is not innate, and everyone has it. It must be learned and cultivated. In education, we should guide students to discover and pay attention to beauty and perceive beauty, which is education The only way to development.

Under the current form of education in China, there has been an unprecedented enthusiasm for aesthetic education research. There are two reasons: the first is that the country has issued an education policy that strongly recommends it, and the second is the actual needs of social development and human life. What effect does it have on educating people? To analyze it from an academic point of view, it is necessary to explore the two characters "beauty" and "education". First of all, looking at aesthetic education from the perspective of "beauty", it pays attention to all beautiful things, looks forward to the creation of beauty, attaches importance to the appreciation of 
beauty, and pays attention to the cultivation of beauty. From the point of view of aesthetic education, aesthetic education is an important organic part of education. Both of them take educating people as an important goal. Aesthetic education can be understood as education for cultivating a correct aesthetic point of view and a healthy aesthetic taste, or it can be understood as training Humanistic literacy, artistic literacy, noble character, and education for all-round physical and mental development. The author believes that aesthetic education is organized, planned, and purposeful. In all kinds of art classroom teaching, students' aesthetic abilities, including appreciation, performance, and creativity, is cultivated to stimulate students' perception of beauty, shape students' moral sentiments, and coordinate students, fully physical and mental development.

In summary, it can be clearly understood that aesthetic education has the function of cultivating aesthetic ability, enhancing comprehensive literacy, and coordinating physical and mental development. The implementation of aesthetic education in education improves the spiritual quality of students and is conducive to the cultivation of people's spirit and self-cultivation., Is conducive to people's perception of the world and life; the implementation of aesthetic education in education is the development of people's comprehensive ability and the objective requirement of cultivating all-round development talents that meet the needs of the future society.

\section{Analysis of the teaching status quo of music appreciation courses in ordinary colleges and universities}

The development of aesthetic education needs to be implemented in conjunction with classroom teaching. The author uses the music appreciation class in ordinary colleges and universities as the carrier of aesthetic education research, discusses the current status of the current music appreciation class in ordinary colleges and universities, and analyzes and points out the problems in the teaching of music appreciation in ordinary colleges and universities. In the author's opinion, as a public course in ordinary colleges and universities, music appreciation courses play a positive role in promoting the quality development of music majors and non-music majors. Music appreciation "is a special spiritual activity for aesthetic subjects when they appreciate music. That is to say, music appreciators have in-depth experience of music works, and then realize the beauty of form and content of music works, and finally obtain spiritual and psychological pleasure and satisfaction." The purpose of setting up music appreciation courses in colleges and universities is to experience music appreciation. To cultivate students' musical literacy, aesthetic taste, aesthetic sense, active creative thinking, and stimulate creative expression. It can be seen that the implementation of aesthetic education in college music appreciation classes can better play the role and significance of aesthetic education in education.

However, the shortcomings in the actual teaching of music appreciation courses in colleges and universities are quite severe. From the perspective of students, most of the students in music appreciation classes are music or art lovers. They are eager to learn about music and enter the world of music. However, they have limited reserves of basic music knowledge and are eager to learn more about music. Appreciation class gains more aesthetic ability, but in actual classroom teaching, over-professional learning leads to excessive learning pressure of non-professional students, but it causes learning difficulties for students, and students eventually lose their confidence in learning; from the current teaching methods Look, the music appreciation class mainly uses the teaching method and the appreciation method as the main teaching methods. In today's era, it has been unable to stimulate the subjective participation of students in the classroom. The music appreciation class has gradually become a "talk show" for the teacher. The interaction with teachers and teaching content is not strong, students lack space for thinking, and the teaching method is too single and outdated, unable to mobilize students' learning motivation; from the perspective of teaching content, 
both Chinese and foreign classic music works are studied in college music appreciation classes , But most of the content is out of the students' existing life foundation and cultural cultivation. Students can only blindly accept the indirect experience from the teacher, and the classroom teaching content highlights the boring and boring content.

In summary, the teaching problems of music appreciation courses in ordinary colleges and universities are prominent. The music appreciation courses that originally cultivated students' aesthetic appeal have changed. Appreciation gains spiritual and psychological pleasure, which has resulted in a morbid teaching situation in which appreciation classes have no feelings to talk about, no aesthetics to participate, and inability to gain. The lessons of music appreciation classes in colleges and universities have reached a bottleneck period, and there is an urgent need to change teaching it is imperative to find new ways of thinking.

\section{Probe into the Teaching Path of Music Appreciation Courses in Colleges and Universities from the Perspective of Aesthetic Education}

In the author's opinion, the implementation of aesthetic education in the music appreciation classroom teaching of ordinary colleges and universities is to cultivate students' perception and experience of the beauty of music and even the beauty of art. There are problems in the teaching of appreciation class. The author will apply new teaching methods in the music appreciation class, explore new teaching methods, to stimulate students' perception and experience of music, and to continuously cultivate students' aesthetic ability, so as to achieve the common sense of aesthetic education, the developmental requirements of students in colleges and universities.

First of all, in the past music appreciation class, through the teacher's explanation, the analysis of notation examples, and the commentary of music critics, the auditory art of music was theoretically and concretely studied to a greater extent, and the students finally gained It is theoretical knowledge, not aesthetic experience. The author believes that as an art form that is invisible and intangible, people can feel its charm only under the dominance of hearing. Therefore, the role of hearing should be paid attention to in the teaching of music appreciation. Hearing is the sensation that everyone is born with and is in a stable state between people. It can touch people's inner experience and generate thinking from inner experience. In the music appreciation class under the vision of aesthetic education, we must pay attention to the role of hearing in teaching. In the classroom, we adhere to the principle of hearing preconceived. Let students listen to music at the beginning of the class, open the auditory sensory channel, and experience the music band in perception. Give him the inner feelings, and the students will get the experience of the beauty of music. Secondly, when students experience and feel the beauty of music, in the classroom, teachers need to guide students to think about what is the beauty of this music, and what is the emotional experience it brings to students?

Let students find answers in thinking and recollection. Teachers can use the answers of students to combine the background of the work, the characteristics of the work form, and the characteristics of music and sound in the teaching content of music appreciation. Discover the composition and form of music beauty in learning, and through continuous accumulation in the listening and thinking of music works, students gradually form the qualities of appreciating, discovering and understanding beauty in music appreciation. Third, in my opinion, the teaching of music appreciation class is not only a process of appreciating music and perceiving the beauty of music, but also needs to be externalized after obtaining aesthetic experience and aesthetic experience, that is, aesthetic expression. When performing aesthetic expressions in the classroom, students talk about their feelings and ideas. Most students in the classroom are introverted and implicit, and the effect is not satisfactory. The author believes that teachers can guide aesthetic expression in 


\section{different ways.}

For example, after students have mastered the elements of the form of appreciation of the work, teachers and students will use the form of dialogue and communication to guide students to use these elements of music to create music, stimulate students' independent exploration and artistic expression ability; guide students to pay attention to multi-disciplinary comprehensive exploration , Pay attention to the interaction between music and painting, dance, photography, architecture and other arts, combine music aesthetic experience and music aesthetic experience in the classroom, share personal music aesthetic experience as a group, and discuss the interactive aesthetics between music and different art disciplines Expression, expressing the musical experience with dance, and expressing the beauty of music with painting, which presents not only the students' aesthetic expression of music, but also the creative expression of students' appreciation of works.

According to the summary, from the perspective of education, the classroom teaching of the above three sections is implemented with the goal of aesthetic education. The students' aesthetic perception and experience are cultivated in listening to music, and in the elements and forms that teachers guide students to think about music. Cultivate students' understanding and exploration of music beauty, and cultivate students' expression and creation of music beauty in their artistic performance. From the summary of this whole set of teaching, the main teaching path of music appreciation courses in ordinary colleges and universities from the perspective of aesthetic education is listening to music -Aesthetic experience-Speculative analysis-Inquiry form-Aesthetic expression, which cultivates students' ability to experience beauty, discover beauty, recognize beauty, and express beauty, and at the same time enhance students' aesthetic appeal, cultivate humanistic and artistic qualities, and integrate aesthetic education into music appreciation A new way of teaching courses.

\section{Conclusion}

In the development of music appreciation courses in ordinary colleges and universities in recent years, the problems existing in both teaching methods and teaching concepts have become prominent. The exploration of the teaching path of music appreciation courses in ordinary colleges and universities from the perspective of aesthetic education is an implementation of national higher education. The response of aesthetic education is also an attempt to change teaching concepts in actual classrooms and to explore new teaching methods. The implementation of aesthetic education in the teaching of music appreciation class is to cultivate students' aesthetic ability and humanistic quality, to enhance students' artistic quality and comprehensive quality, and to cultivate students' noble character and improve their physical and mental health. The author's exploration of the teaching path of the music appreciation course is implemented based on the educational goal of aesthetic education. It aims to cultivate students' artistic experience, artistic performance, and cultivate students' aesthetic ability to discover, recognize, feel, and express beauty to a certain extent. In order to solve the problems exposed in the music appreciation class of ordinary colleges and universities, it is also a teaching of experience, thinking, ability acquisition, and quality improvement in ordinary colleges and universities music appreciation class.

\section{References}

[1] Feng Changchun. 2008. "Fundamentals of Music Aesthetics", Nanjing Normal University Press, 1st edition

[2] Jiang Wei and Li Ye. 2021. "Recognition of Several Issues in Current College Aesthetic Education", "Aesthetic Education Research", 2021, Issue 11, 125-129.

[3] Carl Dalhaus, translated by Yang Yandi: "Introduction to the History of Musical Aesthetic Concepts", Shanghai Music Publishing House, 1st edition, July 2006.

[4] Teng Shouyao: "Returning to Ecological Art Education", Nanjing Publishing House, 2008 edition. 
[5] Guan Jianhua: "Cultural Vision of Chinese Music Aesthetics", Nanjing Normal University Press, 2013 edition. [6] Ministry of Education: "Opinions of the Ministry of Education on Effectively Strengthening the Work of Aesthetic Education in Colleges and Universities in the New Era", Jiaotiyi [2019] No. 2.

[7] General Office of the State Council: "Opinions on Comprehensively Strengthening and Improving School Aesthetic Education", Guobanfa [2015] No. 71. 